\title{
A novel method to prepare of silane based superhydrophobic thin film
}

\author{
Atilla Evcin', a) and Büşra Dalkılınç2,b) \\ ${ }^{1}$ Afyon Kocatepe University, Materials Science and Engineering Department, 03200, Afyonkarahisar, Turkey \\ ${ }^{2}$ Afyon Kocatepe University, Biomedical Engineering Department, 03200, Afyonkarahisar, Turkey \\ a) Corresponding author: evcin@aku.edu.tr orcid id: 0000-0002-0163-5097 \\ b) busradalkilincbs@gmail.com orcid id:0000-0002-0917-9620
}

(Received date: 24.12.2021 and Accepted date: 30.12.2021)

(DOI: 10.29228/JCHAR. )

REFERENCES: Evcin A., Dalkılınç B., A novel method to prepare of silane based superhydrophobic thin film, Journal of Characterization, (1), Special Issue, 8-18, 2021.

\begin{abstract}
In this study, an organic-inorganic hybrid material was first prepared by the sol-gel method. 3aminopropyltriethoxysilane (3-APTES) and tridecafluorooctyltriethoxysilane (Evonik F 8261) were used as precursors. The silane coupling agents were dissolved in a mixture of water, decane and hydrochloric acid for 2 hours. Soda-lime glass substrates were coated with the silane-based coating solution with the aid of a film applicator. The coated films were dried in an oven at $80^{\circ} \mathrm{C}$ to allow alcohol, organic solvent and excess water to evaporate from the films. After evaporation of the solvents, the samples were characterized by contact angle, FT-IR, SEM, goniometer, light transmittance, haze and gloss meter. Superhydrophobic surface was successfully obtained from 3 APTES/tridecafluorooctyltriethoxysilane hybrid compounds.
\end{abstract}

Keywords: Thin film, sol-gel method, hybrid materials, superhydrophobic, contact angle.

\section{Silan bazlı süperhidrofobik ince film hazırlamak için yeni bir yöntem}

Öz

Bu çalışmada ilk olarak organik-inorganik bir hibrit malzeme sol-jel yöntemi ile hazırlanmıştır. Öncü olarak 3-aminopropyltriethoxysilan (3-APTES) ve tridecafluorooctyltriethoxysilan (Evonik F 8261) kullanıldı. Silan birleştirme ajanları su, dekan ve hidroklorik asit karışımı içerisinde 2 saat çözündürüldü. Soda-kireç cam substratları, bir film aplikatörü yardımı ile silan bazlı kaplama çözeltisi ile kaplandı. Kaplanan filmler, alkol, organik çözücü ve fazla suyun filmlerden buharlaşmasına izin vermek için bir firında $80^{\circ} \mathrm{C}^{\prime} \mathrm{de}$ kurutuldu. Çözücülerin buharlaştırılmasından sonra numuneler, temas açısı, FT-IR, SEM, gonyometre, 1şık geçirgenliği, haze ve parlaklık ölçer cihazı ile karakterize edildi. Süperhidrofobik yüzey, 3-APTES / tridecafluorooctyltriethoxysilane hibrid bileşiğinden başarıyla elde edildi.

Anahtar Kelimeler: İnce film, sol-jel yöntemi, hibrit malzemeler, süperhidrofobik, temas açısı. 


\section{Introduction}

When coating a surface, layers that do not exceed a few micrometers in thickness are called thin films. Thin films, which are of great interest among recent research studies, are used in the advancement of electronic devices in the maritime industry, the automotive industry, the healthcare industry, the aerospace industry and many more [1]. Differences in production methods and conditions of production methods reveal many different properties in thin films. These features provide thin film materials with superior properties compared to other materials and guide new studies. With the development of technology, many new production techniques have emerged and developed in the production of thin films [2]. Thin film production techniques are divided into various subgroups according to the physical and chemical properties of the material surfaces and their physical state [1]. Electroplating method is the coating process of the metal layer by forming discharge points on the conductive surfaces that act as cathodes in the electrolysis vessel [3]. Electroless plating is a simple way to produce various metals with high impact and improved mechanical properties by deposition of nickel without the use of electric current [4]. The spray pyrolysis coating method consists of the atomization of a liquid solution by blowing air towards the heated surface [5]. Thermochemical coating is a type of coating that forms nitride, carbide or boride layers on the material surface to improve the surface [6]. In the coating process with thermal spraying, the raw material particles to be used in the coating are pushed to the surface to be coated at high speed, while they are heated by the gas in the system and the surface is coated [7]. Chemical vapor deposition (CVD) is the process in which the substrate is exposed to one or more volatile precursors that can react and decompose on the substrate surface to produce the desired thin film residue [8]. The physical vapor deposition method (PVD) can be summarized as the process of bonding the solid raw material to the material to be coated in a controlled manner by turning it into plasma with high energy [9].

Sol-gel technique is one of the thin film production techniques. Sol-gel technology began to be used in the 1800s [10]. Sol-gel process has been an important, widespread and widely popular method for the preparation of thin films due to its advantages. Its applications are wide, offering several advantages over other methods, including good homogeneity, low cost, and high purity [11]. The sol-gel method can be used in the production of almost all single-component or multi-component oxide films. The sol-gel process involves the formation of colloidal suspensions (sol) of solid particles in the liquid phase and then threedimensional solid inorganic networks (gel) in a continuous liquid phase [12]. Sol-gel method is a coating technique applied to improve the surface properties of glass, ceramic, metal and plastic backings and to gain new properties such as optics, electronics, chemicals and mechanics [13]. In our study, a colloidal suspension (left) was formed using 3-APTES and Evonik F8261 materials and used to form thin films.

Hybrid materials are of great interest as a new class of materials due to their original properties based on the combination of organic and inorganic polymers $[14,15]$. As a result of the combination of organic and inorganic materials in the same material with the appropriate processing method, new properties emerge in terms of mechanical, electrical, physical or optical properties [14,16]. However, their biocompatibility, biodegradation and chemical structure have also been among the research topics. Hybrid materials have revealed new developments in the creation of various smart and functional materials [17]. The chemistry of the silane surface modification reaction is shown in Figure 1 [18]. In our study, a hybrid material was obtained by combining organic 3-APTES and inorganic Evonik F8261 with strong bonds and coated as a thin film on the glass surface.

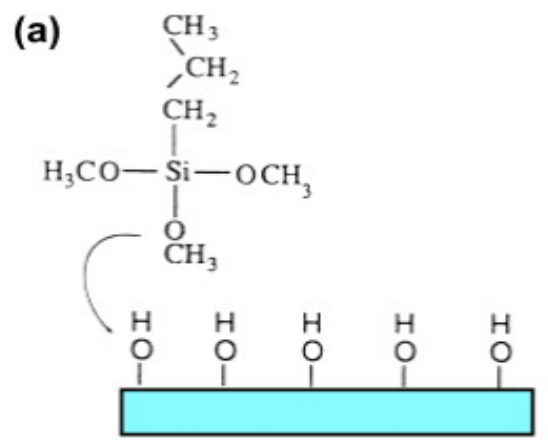

Figure 1. Silane surface modification reaction [18] 


\section{Journal of Characterization}

The introduction of superhydrophobic surfaces into the scientific world began with the study of the lotus flower, which is known to be constantly clean in muddy and dirty environments. Inspired by the lotus flower, attempts have been made about the water holding and repellent properties of solid surfaces [19]. Examples of these initiatives are self-cleaning artificial and smart surfaces by removing water and pollutants. The protective effects on artificial surfaces are enhanced [20,21].

When contact is established between a liquid and a solid, the angle between the liquid surface and the solid surface is defined as the contact angle [22,23]. Whether a surface is hydrophobic or hydrophilic is measured by the contact angle between the water and the surface [18,19,24]. Figure 2 shows the different situations that the sui le surface can create [25]. Surface wettability can be classified according to the contact angle $(\theta)$ value as follows:

If $\theta<90^{\circ}$ the surface is hydrophilic

If $\theta<10^{\circ}$ the surface is superhydrophilic

If $\theta>90^{\circ}$ the surface is hydrophobic

If $\theta>150^{\circ}$, the surface is superhydrophobic [26,27].

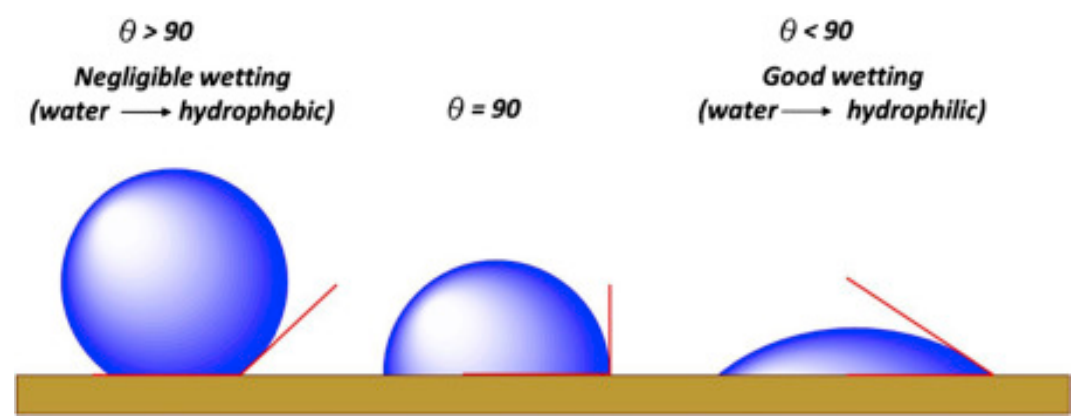

Figure 2. Surface wettability according to contact angle

\section{Material and Method}

In experimental studies, 3-aminopropyltriethoxysilane (3-APTES) (Merck ), tridecafluorooctyltriethoxysilane (Evonik F 8261) (Aldrich-Sigma), Decane (Merck), Hydrochloric acid (1M) and pure water were used as precursors. Materials were used as supplied.

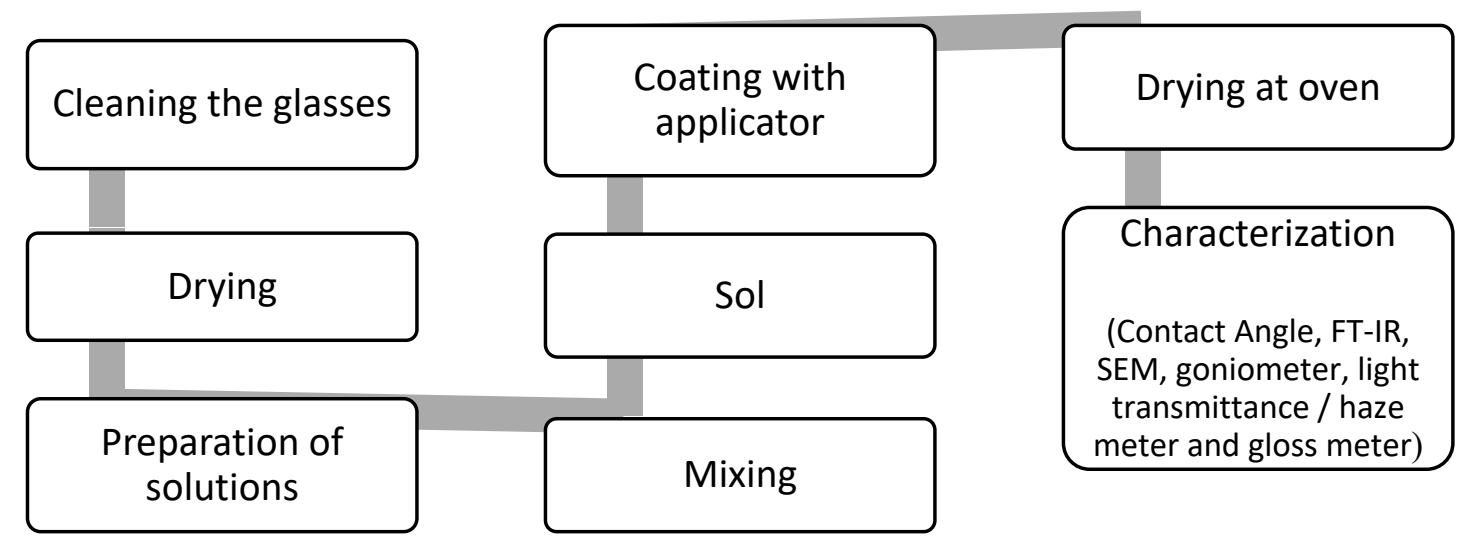

Figure 3. Experiment flow chart 


\section{Journal of Characterization}

\subsection{Preparation of Glass Surfaces}

In the whole study, rectangular glass surfaces of $2.5 \times 7.5 \mathrm{~cm}$ were used as the surface. To achieve an ideal coating layer, the glass substrates were cleaned with the cleaning procedure described below. For surface pretreatment, the glass surfaces were ultrasonically cleaned with double distilled water for 10 minutes. The chemical cleaning procedure was carried out by soaking the glass substrates in $\mathrm{NaOH}$, Purified water, $\mathrm{H} 3 \mathrm{PO} 4$, Purified water for 5 minutes, respectively. All glass surfaces were dried at $80{ }^{\circ} \mathrm{C}$ for $2 \mathrm{~h}$ before coating. Thus, it was made ready for use.

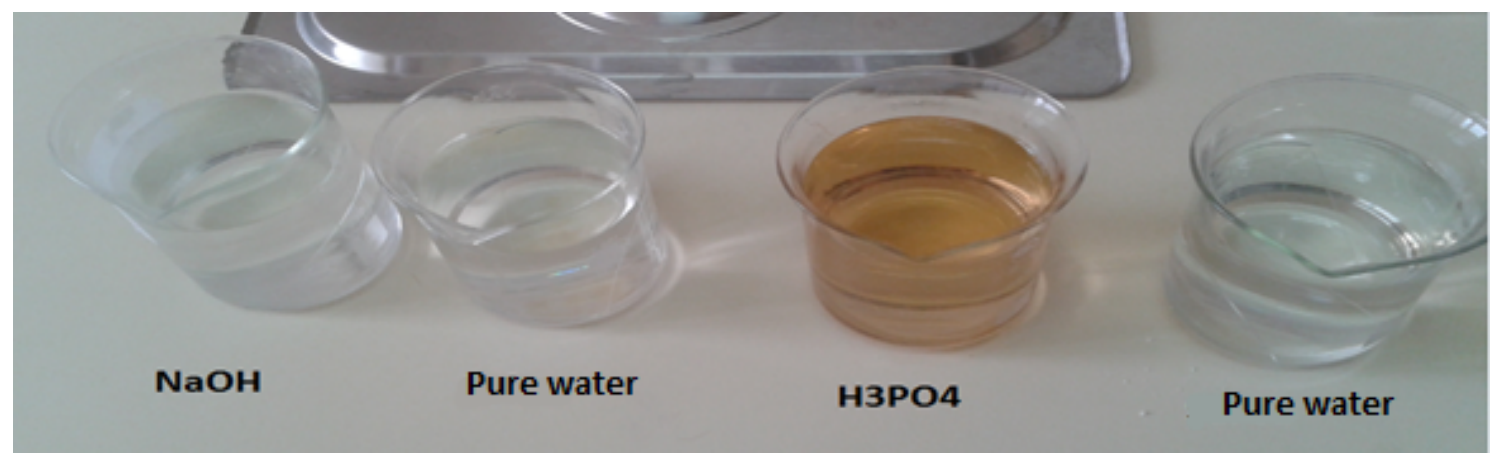

Figure 4. Glass cleaning procedure

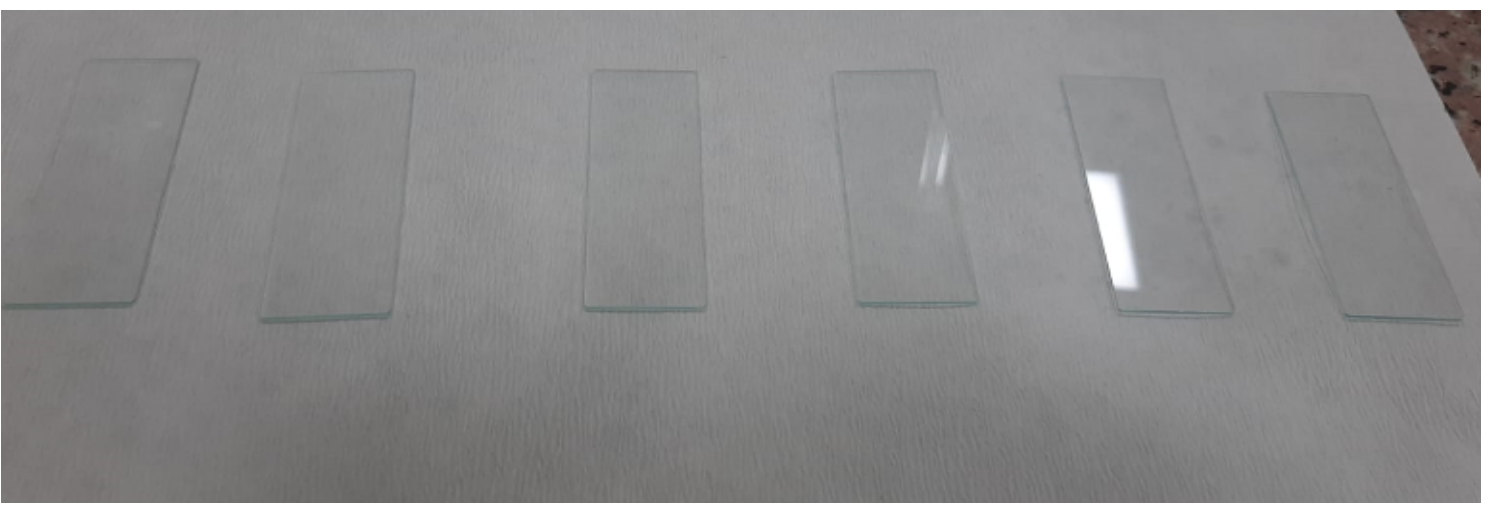

Figure 5. Cleaned glass surfaces

In the experimental study, three different solutions were prepared and coated on six glass samples. It is aimed to impart hydrophobic or superhydrophobic properties to hydrophilic glasses.

Table 1. Composition of prepared solutions

\begin{tabular}{l|l|l|l}
\hline & Recipe-1 & Recipe-2 & Recipe-3 \\
\hline 3-APTES & $3,31 \mathrm{~g}$ & $3,31 \mathrm{~g}$ & $3,31 \mathrm{~g}$ \\
\hline Decane & $10 \mathrm{~g}$ & $10 \mathrm{~g}$ & $10 \mathrm{~g}$ \\
\hline Evonik F8261 & - & $1 \mathrm{~mL}$ & $2 \mathrm{~mL}$ \\
\hline Pure Water & $2 \mathrm{~mL}$ & $2 \mathrm{~mL}$ & $2 \mathrm{~mL}$ \\
\hline Hydrochloric Acid (1M) & & & \\
\hline
\end{tabular}




\subsection{Thin Film Coating on Glass with the Help of Film Applicator}

The prepared solution was taken with a pipette and covered with a film-drawing applicator on previously cleaned and prepared glasses. The windows are covered with a single layer. Two glass samples were coated from each solution. The coated samples were left to dry in an oven at $80^{\circ} \mathrm{C}$. Necessary tests were performed on the drying glass samples and information was obtained about the surface properties.
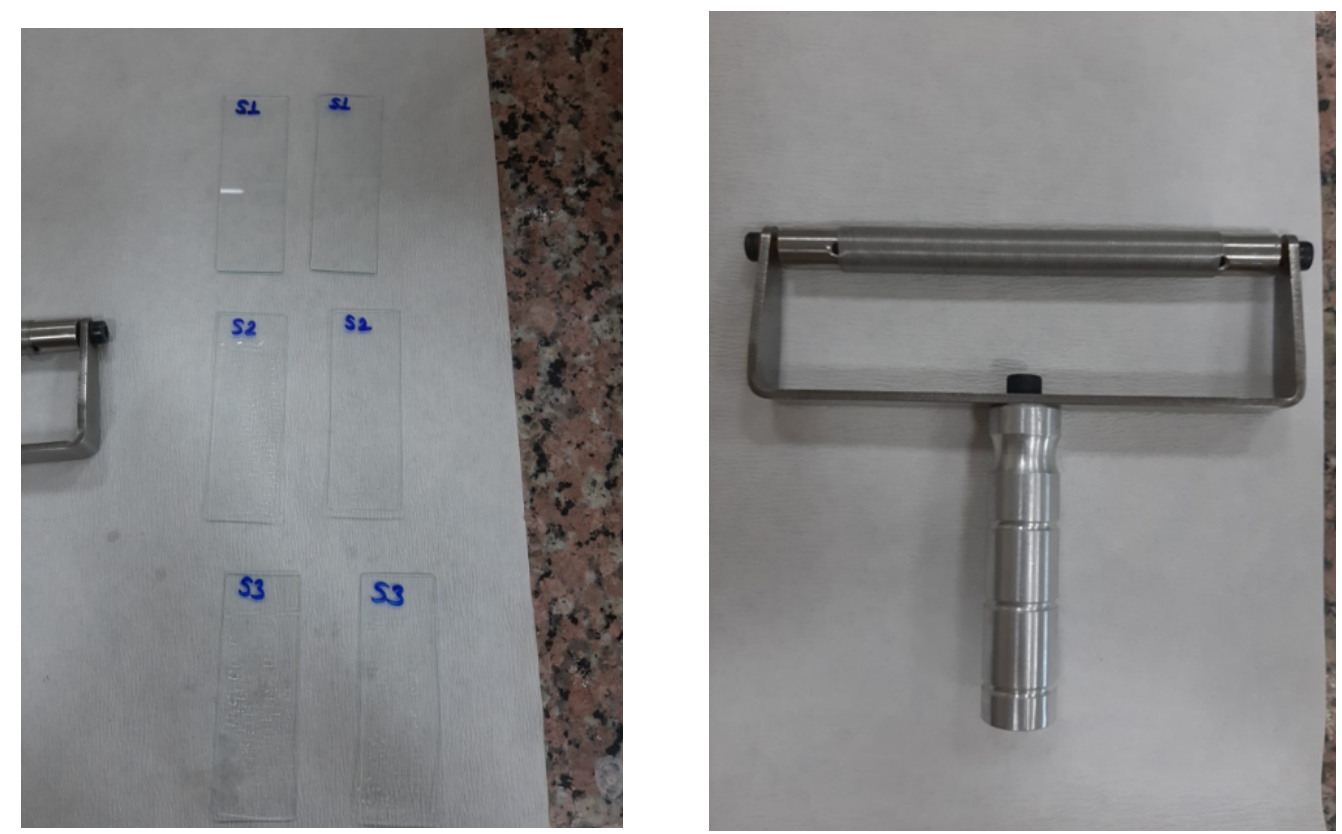

Figure 6. Coated glasses and film applicator

\subsection{Tests applied to samples}

The prepared solution was taken with a pipette and covered with a film-drawing applicator on previously cleaned and prepared glasses. The windows are covered with a single layer. Two glass samples were coated from each solution. The coated samples were left to dry in an oven at $80^{\circ} \mathrm{C}$. Necessary tests were performed on the drying glass samples and information was obtained about the surface properties. 


\section{Results and Discussion}

\subsection{Contact Angle Results}

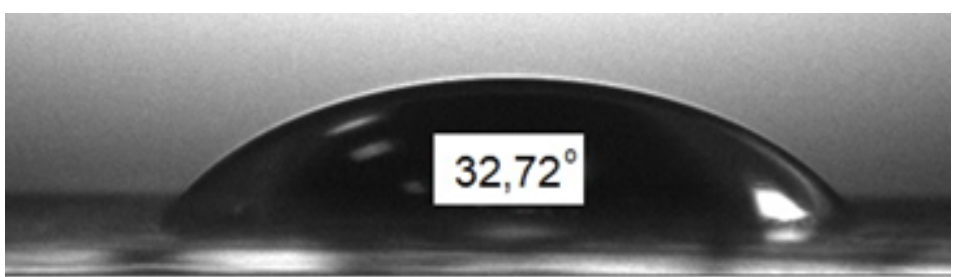

Uncoated Glass

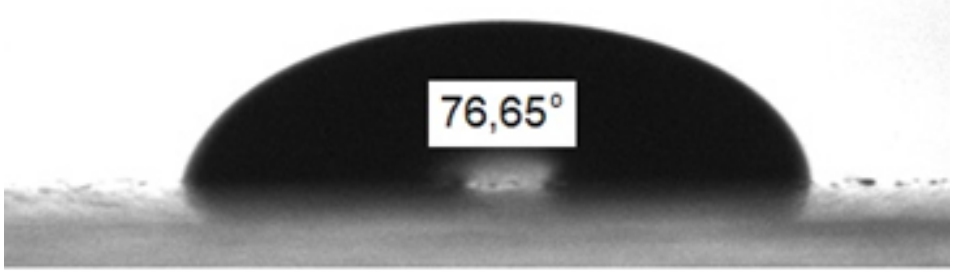

Recipe 1

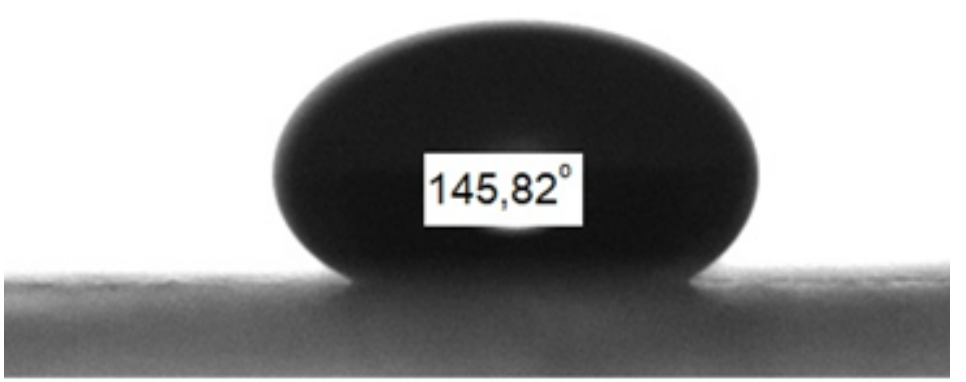

Recipe 2

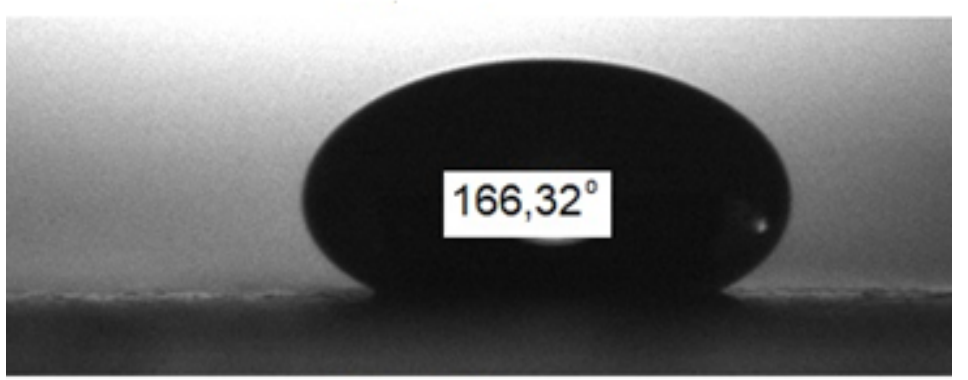

Recipe 3

Figure 7. Contact angle of solution coated surface

As seen in Figure 7, the surface contact angle of the uncoated glass with water was $32^{\circ}$, while the contact angles were found to be $76^{\circ}, 145^{\circ}$ and $166^{\circ}$, respectively, after all three coatings. While the uncoated glass is hydrophilic, a hydrophobic surface was obtained especially in Recipes 2 and 3. Recipe 2 and 3 include tridecafluorooctyltriethoxysilane (Evonik F 8261), one of the fluoroalkyl silane compounds. Increasing the amount of this compound significantly increased the contact angle. 


\subsection{FT-IR Results}

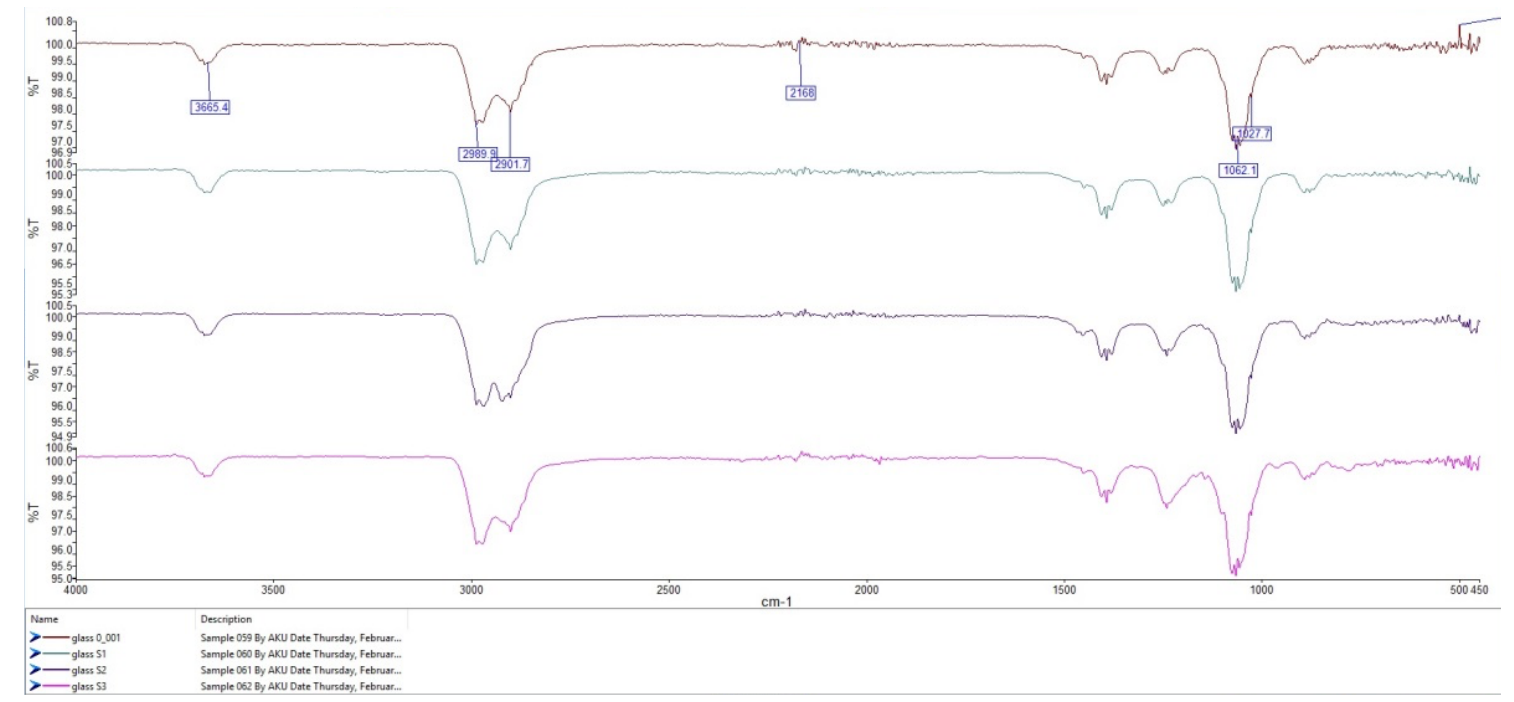

Figure 8. FTIR analysis.

FTIR analysis of coatings is given in Figure 8. The peaks observed at approximately $3665 \mathrm{~cm}-1$ and $2901 \mathrm{~cm}-1$ in hydrophilic glass belong to free or adsorbed water with hydrogen bond interactions. The peak at $1062 \mathrm{~cm}-1$ can be attributed to $\mathrm{Si}-\mathrm{O}-\mathrm{Si}$ mode vibrations. The spectrum is dominated by a broad absorption band between 1250 and $1062 \mathrm{~cm}-1$, which corresponds to the Si-O-C and Si-O-Si vibrations, indicating the presence of the siloxane network as expected. The peak at $1566 \mathrm{~cm}-1$ confirms the presence of primary amines, but the peak around $1655 \mathrm{~cm}-1$ indicates the presence of double-bonded nitrogen as well. The presence of C-F bonds in the form of CF, CF2 or CF3 is also located at 610, 770, 960 and 1,027 $\mathrm{cm}-1$.

\subsection{Light Transmittance / Haze Meter and Gloss Meter}

The results of the tests performed with the Light Transmittance/Haze meter and Luminosity meter shown in Figure 10 are given in Table 2. As can be seen in Table 2, a slight decrease in light transmittance was recorded with the coating. Haze (blur) increased and brightness decreased.

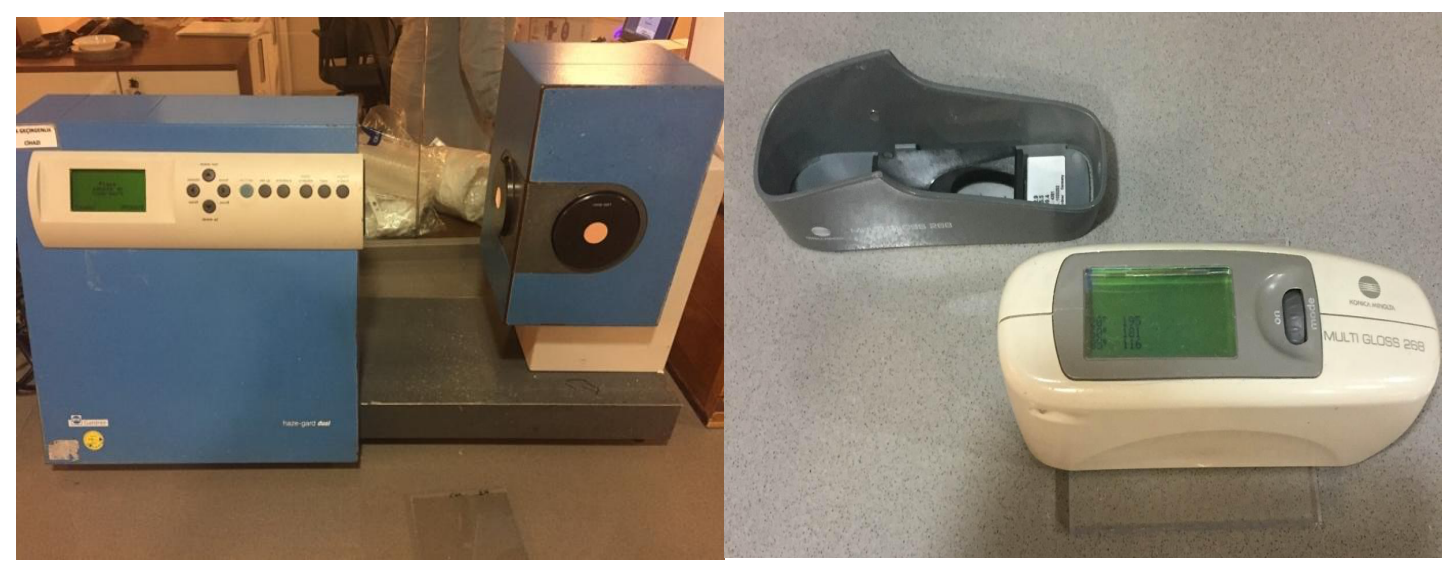

Figure 10. Light transmittance/haze meter and gloss meter used in the experiments 


\section{Journal of Characterization}

Table 2. Light Transmittance / Haze Meter and Gloss Meter Results

\begin{tabular}{l|l|l|l|l}
\hline & GLASS & R1 & R2 & R3 \\
\hline \% Transmittance & 94 & 93 & 92 & 91 \\
\hline \% Haze & 0,54 & 1,14 & 2,65 & 4,42 \\
\hline Brightness $\left(60^{\circ}\right)$ & 174 & 165 & 156 & 148 \\
\hline
\end{tabular}

\subsection{SEM Results}
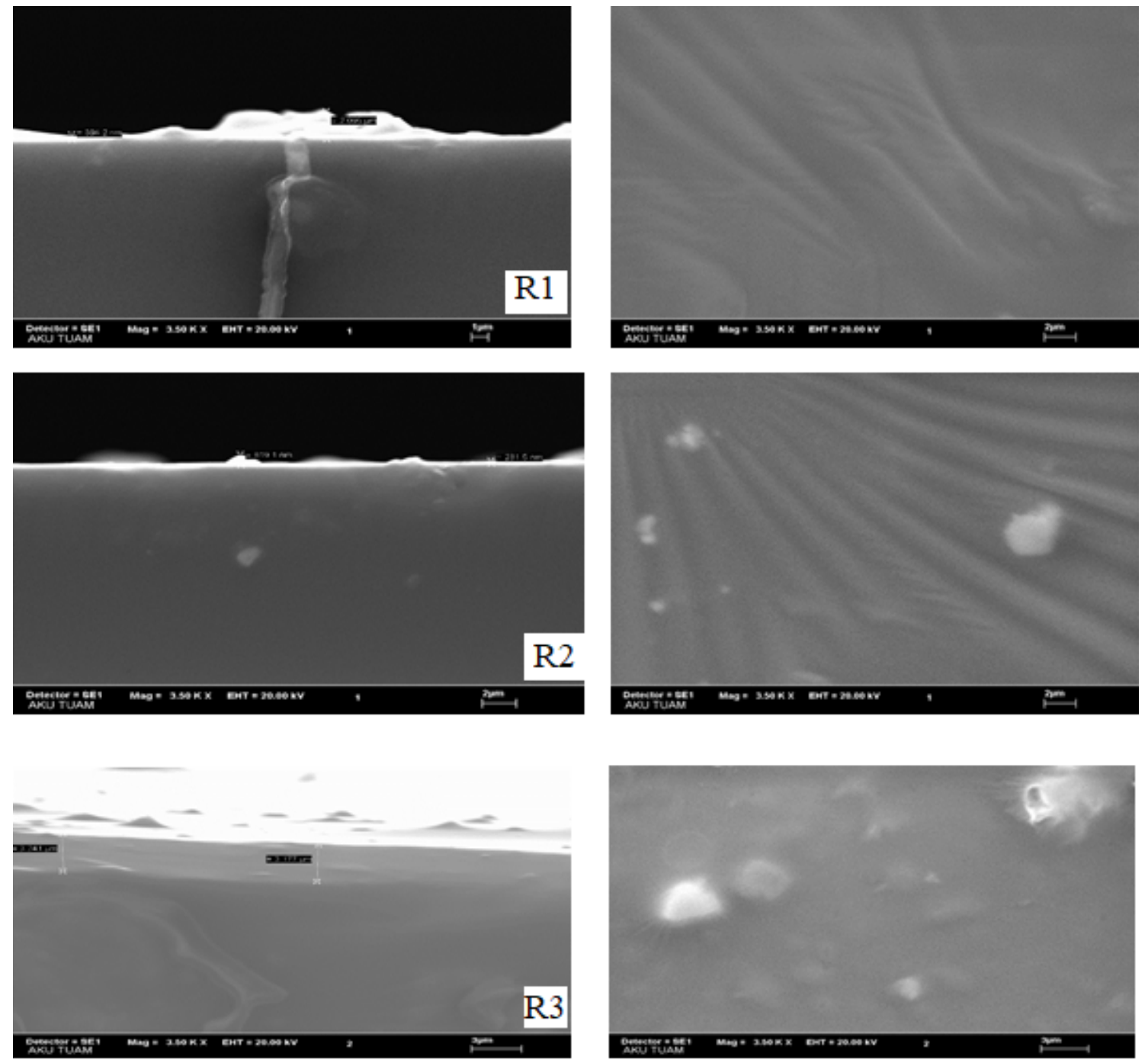

Figure 9. Scanning electron microscopy (SEM) analyzes of prescriptions 
As can be seen from the cross-sections of the SEM photographs in Figure 9, the layers coated on the glass are less than 2 micrometers thick. It can be seen from the surface pictures that it is homogeneously dispersed and no cracks occur.

\section{Conclusions and Recommendations}

In this study, silane-based organic-inorganic hybrid coating was successfully formed on the glass surface by sol-gel method. Amino-based silane and fluoro silane compounds formed a superhydrophobic layer on the glass surface. Maximum contact angle is 166 degree. Thickness of layer is about 2 micrometers and homogenous surface was obtained by sol-gel method.

\section{Acknowledge}

I would like to thank Afyon Kocatepe University Institute of Science and Scientific Research Projects Coordination Unit (BAPK) for the support of the project numbered 20.FEN.BİL.30.

\section{References}

[1] SÖNMEZOĞLU, S., Mehmed, K. O. Ç., \& Seçkin, A. K. I. N. (2012). İnce film üretim teknikleri. Erciyes Üniversitesi Fen Bilimleri Enstitüsü Fen Bilimleri Dergisi, 28(5), 389-404.

[2] Gessert, Timothy. (2012). Chapter 1.19: Cadmium Telluride Photovoltaic Thin Film: CdTe. Earth and Planetary Sciences. 1. 10.1016/B978-0-08-087872-0.00122-0.

[3] Zhang, B., Li, B., Gao, S., Li, Y., Cao, R., Cheng, J., ... \& Liu, B. (2020). Y-doped $\mathrm{TiO} 2$ coating with superior bioactivity and antibacterial property prepared via plasma electrolytic oxidation. Materials \& Design, 192, 108758.

[4] Vetrivezhan, P., Ayyanar, C., Arunraj, P. V., Vasanthkumar, P., \& Ganesan, D. (2021). Electroless deposition of aluminium alloy LM25 by $\mathrm{SiC}$ and Ni-P nano coating. Materials Today: Proceedings.

[5] Weber, S. B., Lein, H. L., Grande, T., \& Einarsrud, M. A. (2013). Influence of the precursor solution chemistry on the deposition of thick coatings by spray pyrolysis. Surface and Coatings Technology, 221, 53-58.

[6] Günen, A., Kanca, Y., Karahan, İ. H., Karakaş, M. S., Gök, M. S., Kanca, E., \& Çürük, A. (2018). A comparative study on the effects of different thermochemical coating techniques on corrosion resistance of STKM-13A steel. Metallurgical and Materials Transactions A, 49(11), 5833-5847.

[7] Mostaghimi, J., Chandra, S., Ghafouri-Azar, R., \& Dolatabadi, A. (2003). Modeling thermal spray coating processes: a powerful tool in design and optimization. Surface and Coatings Technology, 163, 1-11. 
[8] Martin, P. M. (2009). Handbook of deposition technologies for films and coatings: science, applications and technology. William Andrew.

[9] Liu, M. J., Zhang, K. J., Zhang, Q., Zhang, M., Yang, G. J., Li, C. X., \& Li, C. J. (2019). Thermodynamic conditions for cluster formation in supersaturated boundary layer during plasma spray-physical vapor deposition. Applied Surface Science, 471, 950-959.

[10] Akpan, UG ve Hameed, BH (2010). Katk1lı TiO2 fotokatalizörlerinin sol-jel yöntemindeki gelişmeler. Uygulamalı Kataliz A: 375 (1), 1-11.

[11] Chen, D. H., \& He, X. R. (2001). Synthesis of nickel ferrite nanoparticles by sol-gel method. Materials Research Bulletin, 36(7-8), 1369-1377.

[12] Wang, Y. T., Zhang, X. T., Xu, J. B., Shen, Y., Wang, C. A., Li, F. W., ... \& Shen, R. Q. (2020). Fabrication and characterization of $\mathrm{Al}-\mathrm{CuO}$ nanocomposites prepared by sol-gel method. Defence Technology.

[13] Qu, L., Rahimi, S., Qian, J., He, L., He, Z., \& Yi, S. (2020). Preparation and characterization of hydrophobic coatings on wood surfaces by a sol-gel method and post-aging heat treatment. Polymer Degradation and Stability, 109429.

[14] Zhang, Q., Zhang, X., Cheng, W., Li, Z., \& Li, Q. (2020). In situ-synthesis of calcium alginate nano-silver phosphate hybrid material with high flame retardant and antibacterial properties. International Journal of Biological Macromolecules, 165, $1615-1625$.

[15] Zhao, X., Li, Z., Guo, Q., Yang, X., \& Nie, G. (2021). High performance organicinorganic hybrid material with multi-color change and high energy storage capacity for intelligent supercapacitor application. Journal of Alloys and Compounds, 855, 157480 .

[16] Wang, Y., Fan, H., Wong, P. K., Wu, Y., \& Rittmann, B. (2021). Biodegradation of tetracycline using hybrid material (UCPs-TiO2) coupled with biofilms under visible light. Bioresource Technology, 323, 124638.

[17] Rejab M.R., Hamdan M.H., Quanjin M., Siregar J.P., Bachtiar D., Muchlis Y. Historical Development of Hybrid Materials. Mat. Sci. Mat. Eng. 2020;4:445-455. doi: 10.1016/j.pmatsci.2015.12.001

[18] Ratner, B. D., Hoffman, A. S., \& McArthur, S. L. (2020). Physicochemical surface modification of materials used in medicine. In Biomaterials science (pp. 487-505). Academic Press.

[19] Xia, Z., Xiao, Y., Yang, Z., Li, L., Wang, S., Liu, X., \& Tian, Y. (2019). Droplet impact on the super-hydrophobic surface with micro-pillar arrays fabricated by hybrid laser ablation and silanization process. Materials, 12(5), 765. 
[20] Raibeck, L., Reap, J., \& Bras, B. (2009). Investigating environmental burdens and benefits of biologically inspired self-cleaning surfaces. CIRP Journal of Manufacturing Science and Technology, 1(4), 230-236.

[21] Wang, X., Jing, C., Chen, Y., Wang, X., Zhao, G., Zhang, X., Zhang, Y. (2020). Active corrosion protection of super-hydrophobic corrosion inhibitor intercalated $\mathrm{Mg}-\mathrm{Al}$ layered double hydroxide coating on AZ31 magnesium alloy. Journal of Magnesium and Alloys, 8(1), 291-300.

[22] Zhenyu, S., Zhanqiang, L., Hao, S., \& Xianzhi, Z. (2016). Prediction of contact angle for hydrophobic surface fabricated with micro-machining based on minimum Gibbs free energy. Applied Surface Science, 364, 597-603.

[23] Gallardo-Moreno, A. M., Navarro-Pérez, M. L., Vadillo-Rodríguez, V., Bruque, J. M., \& González-Martín, M. L. (2011). Insights into bacterial contact angles: Difficulties in defining hydrophobicity and surface Gibbs energy. Colloids and Surfaces B: Biointerfaces, 88(1), 373-380.

[24] Yi, S. W., Yu, I. K., Kim, W. J., \& Choi, S. H. (2021). Cold Plasma Deposition of Polymeric Nanoprotrusion, Nanoparticles, and Nanofilm Structures on a Slide Glass Surface. Processes 2021, 9.

[25] Hebbar, R. S., Isloor, A. M., \& Ismail, A. F. (2017). Contact angle measurements. In Membrane characterization. Elsevier.

[26] Xia, Z., Zhao, Y., Yang, Z., Yang, C., Li, L., Wang, S., \& Wang, M. (2021). The simulation of droplet impact on the super-hydrophobic surface with micro-pillar arrays fabricated by laser irradiation and silanization processes. Colloids and Surfaces A: Physicochemical and Engineering Aspects, 612, 125966.

[27] Karim, A. M., Rothstein, J. P., \& Kavehpour, H. P. (2018). Experimental study of dynamic contact angles on rough hydrophobic surfaces. Journal of colloid and interface science, 513, 658-665. 